\title{
Amelioration of chronic fluoride toxicity by calcium and fluoride-free water in rats
}

\author{
Priyanka Shankar ${ }^{1}$, Sudip Ghosh ${ }^{2}$, K. Bhaskarachary ${ }^{3}$, K. Venkaiah ${ }^{4}$ and Arjun L. Khandare ${ }^{1 *}$ \\ ${ }^{1}$ National Institute of Nutrition, Food and Drug Toxicology Research Centre, Indian Council of Medical Research, \\ Hyderabad 500 007, India \\ ${ }^{2}$ Molecular Biology Unit, National Institute of Nutrition, Indian Council of Medical Research, Hyderabad 500 007, India \\ ${ }^{3}$ Food Chemistry Division, National Institute of Nutrition, Indian Council of Medical Research, Hyderabad 500 007, India \\ ${ }^{4}$ Biostatistics Division, National Institute of Nutrition, Indian Council of Medical Research, Hyderabad 500 007, India \\ (Submitted 27 April 2012 - Final revision received 17 September 2012 - Accepted 17 September 2012 - First published online 11 December 2012)
}

\section{Abstract}

The study was undertaken to explore the amelioration of chronic fluoride (F) toxicity (with low and normal Ca) in rats. The study was conducted in two phases. In phase I (6 months), seventy-six Wistar, weanling male rats were assigned to four treatment groups: normal-Ca $(0.5 \%)$ diet (NCD), Ca+F-; low-Ca (0.25\%) diet (LCD), Ca-F-; NCD + 100 parts per million (ppm) F water, Ca+F+; LCD $+100 \mathrm{ppm} F$ water, $\mathrm{Ca}-\mathrm{F}+$. In phase II (reversal experiment, 3 months), LCD was replaced with the NCD. Treatment groups Ca+F+ and $\mathrm{Ca}-\mathrm{F}+$ were divided into two subgroups to compare the effect of continuation $v$. discontinuation along with Ca supplementation on reversal of chronic F toxicity. In phase I, significantly reduced food efficiency ratio (FER), body weight gain (BWG), faecal F excretion, serum $\mathrm{Ca}$ and increased bone $\mathrm{F}$ deposition were observed in the treatment group $\mathrm{Ca}-\mathrm{F}+$. Reduced serum 25 -hydroxy-vitamin $\mathrm{D}_{3}$, increased 1,25-dihydroxy-vitamin $\mathrm{D}_{3}$ and up-regulation of Ca-sensing receptor, vitamin $\mathrm{D}$ receptor and S100 Ca-binding protein $\mathrm{G}$ (S100G) were observed in treatment groups $\mathrm{Ca}-\mathrm{F}-$ and $\mathrm{Ca}-\mathrm{F}+$. In phase II (reversal phase), FER, BWG and serum Ca in treatment groups $\mathrm{Ca}-\mathrm{F}+/ \mathrm{Ca}+\mathrm{F}-$ and $\mathrm{Ca}-\mathrm{F}+/ \mathrm{Ca}+\mathrm{F}+$ were still lower, as compared with other groups. However, other variables were comparable. Down-regulation of $\mathrm{S} 100 \mathrm{G}$ was observed in $\mathrm{F}-$ fed groups $(\mathrm{Ca}+\mathrm{F}+/ \mathrm{Ca}+\mathrm{F}+$ and $\mathrm{Ca}-\mathrm{F}+/ \mathrm{Ca}+\mathrm{F}+)$ in phase II. It is concluded that low $\mathrm{Ca}$ aggravates $\mathrm{F}$ toxicity, which can be ameliorated after providing adequate $\mathrm{Ca}$ and F-free water. However, chronic $\mathrm{F}$ toxicity can interfere with Ca absorption by down-regulating S100G expression irrespective of Ca nutrition.

Key words: Chronic fluoride toxicity: Rats: Low calcium: Calcium homeostasis

Chronic fluoride (F) toxicity is caused due to exposure to excess $\mathrm{F}>1.5$ parts per million (ppm) ${ }^{(1)}$, mainly through water and is endemic in twenty-five countries across the globe. In India, F endemicity has been reported in 196 districts of nineteen states and is considered as a public health problem ${ }^{(2)}$. Chronic F toxicity is categorised as dental, skeletal and non-skeletal fluorosis, based on the tissue affected. The very first sign of chronic F toxicity is exhibited by teeth, i.e. dental mottling, called dental fluorosis $^{(3)}$. Skeletal fluorosis progresses in a slow manner and, therefore, is not clinically visible in its initial phase. Clinical symptoms of skeletal fluorosis include restricted movements of joints, stiffness and deformities of the spine such as kyphosis, bony exostoses and paraplegia due to spinal compression ${ }^{(4)}$. Non-skeletal fluorosis affects tissues other than the dental and skeletal system such as the gastrointestinal tract, brain, muscle, etc. Any kind of manifestation in these organs of inhabitants of fluorotic areas may indicate non-skeletal fluorosis ${ }^{(3)}$.

Apart from these well-defined clinical symptoms, reduced food intake and body weight gain (BWG) have been observed in F-fed animals ${ }^{(5-8)}$. However, other studies did not show any difference in $\mathrm{BWG}^{(9)}$ in F-fed animals. The reason behind this contradiction may be due to different species used, dose of $\mathrm{F}$ and duration of the study. Moreover, none of the aforementioned studies have reported food efficiency ratio (FER), which is an important measure of the food converted into BWG.

It has also been reported that chronic exposure to $\mathrm{F}$ may disturb Ca homeostasis by producing hypocalcaemia due to its stimulating effect on osteoblastic cell proliferation ${ }^{(10-12)}$, resulting in an increase in bone formation ${ }^{(13-15)}$, which needs extra $\mathrm{Ca}$. This alteration of extracellular $\mathrm{Ca}$ level is

Abbreviations: $1,25(\mathrm{OH})_{2}$ vitamin $\mathrm{D}_{3}, 1,25$-dihydroxy-vitamin $\mathrm{D}_{3} ; 25(\mathrm{OH})$ vitamin $\mathrm{D}_{3}$, 25-hydroxy-vitamin $\mathrm{D}_{3}$; BWG, body weight gain; CASR, Ca-sensing receptor; FER, food efficiency ratio; FFW, F-free water; LCD, low-Ca (0.25\%) diet; NCD, normal-Ca (0.5\%) diet; ppm, parts per million; S100G, S100 Ca-binding protein G; VDR, vitamin D receptor.

*Corresponding author: Dr A. L. Khandare, email alkhandare@yahoo.com 
sensed by Ca-sensing receptor (CASR) ${ }^{(16)}$ and the parathyroid glands are triggered to secrete more parathyroid hormone to combat the $\mathrm{Ca}$ imbalance in the body, producing secondary hyperparathyroidism ${ }^{(14,17)}$. Parathyroid hormone triggers the conversion of 25-hydroxy-vitamin $\mathrm{D}_{3}\left(25(\mathrm{OH})\right.$ vitamin $\left.\mathrm{D}_{3}\right)$ to 1,25-dihydroxy-vitamin $\mathrm{D}_{3}\left(1,25(\mathrm{OH})_{2}\right.$ vitamin $\left.\mathrm{D}_{3}\right)$ in the proximal convoluted tubule of the kidneys ${ }^{(18)}$ to maintain plasma ionised $\mathrm{Ca}$ concentrations within narrow physiological limits by acting on the intestine, kidneys and bone ${ }^{(18)}$ through its receptor - vitamin D receptor $(\mathrm{VDR})^{(19)} .1,25(\mathrm{OH})_{2}$ vitamin $\mathrm{D}_{3}$ alters the transcription of S100 Ca-binding protein G (S100G) in the intestine ${ }^{(20,21)}$ to increase $\mathrm{Ca}$ absorption. In a study carried out in rats fed $50 \mathrm{ppm} \mathrm{F}$ for 6 weeks, it was found that $\mathrm{F}$ exhibited an inhibitory effect on duodenal $V D R$ and $S 100 G$ gene transcription, thereby reducing Ca absorption ${ }^{(22)}$. However, serum parathyroid hormone was not assessed in the study.

Preliminary research carried out in F-fed rats ${ }^{(23)}$ and kittens ${ }^{(24)}$ showed that dietary $\mathrm{Ca}$ reduces $\mathrm{F}$ toxicity. It was suggested that a possible mechanism of action is the formation of insoluble calcium fluoride, which is excreted through faeces. Further, a Ca balance study carried out in human fluorotic subjects showed increased retention of $\mathrm{Ca}$ because of decreased faecal and urinary $\mathrm{Ca}$, suggesting enhanced absorption of $\mathrm{Ca}$ at the kidney as well as the intestine ${ }^{(25)}$. Similar observations were reported in F-fed monkeys also ${ }^{(26)}$. It was proposed that on a given intake of $\mathrm{F}$, increased intake of $\mathrm{Ca}$ might lead to the formation and deposition of calcium fluoride in bone, thereby reducing $\mathrm{F}$ in the non-osseous tissues. Furthermore, many other researchers reported that the adverse effects of $\mathrm{F}$ could be more aggravated in the presence of a low dietary Ca intake ${ }^{(11,27,28)}$

According to the National Nutrition Monitoring Bureau (India) report, the average dietary $\mathrm{Ca}$ intake of the Indian population (including fluorotic areas) is $335 \mathrm{mg} / \mathrm{d}$ and the average consumption of milk and milk products is $82 \mathrm{~g} / \mathrm{d}^{(29)}$, contrary to RDA of $600 \mathrm{mg} / \mathrm{d}$ and $200 \mathrm{ml} / \mathrm{d}$ for $\mathrm{Ca}$ and milk, respectively ${ }^{(30)}$. Consumption of a phytate-rich diet worsens the condition of low dietary $\mathrm{Ca}$ intake by reducing the absorption of dietary $\mathrm{Ca}^{(31)}$, which makes the Indian population more vulnerable to fluorosis. Recently, a pilot project on the prevention and control of fluorosis in six districts of the fluorotic areas has been started in India, which targets comprehensive prevention and management of fluorosis by training of health professionals, community nutrition education (especially for intake of dairy products and Ca-rich foods) and providing F-free water (FFW) wherever possible ${ }^{(32)}$. However, rehabilitation of fluorotic patients is still an issue and reversibility of fluorosis has not been studied adequately. In addition, some gaps still exist in the current knowledge. Studies related to chronic effects of $\mathrm{F}$ on $\mathrm{Ca}$ homeostasis and expression of genes involved in Ca homeostasis are scanty.

Based on previous studies, we hypothesised that low Ca aggravates chronic F toxicity, which can be ameliorated by providing normal $\mathrm{Ca}$ and $\mathrm{FFW}$. The objectives were as follows: (1) to study the effect of F on food intake, FER, Ca homeostasis and expression of genes involved in Ca homeostasis under adequate or inadequate $\mathrm{Ca}$ and (2) to explore the effect of FFW and adequate $\mathrm{Ca}$ on amelioration of chronic F toxicity.

\section{Materials and methods}

\section{Animals and maintenance}

A total of seventy-six, Wistar, weanling, male rats (body weight 55 (SEM 15) g) were obtained from the National Centre for Laboratory Animal Sciences, National Institute of Nutrition, Hyderabad, India. Rats were housed individually in hanging polyvinyl wire-bottomed cages and maintained at controlled conditions $\left(22 \pm 2{ }^{\circ} \mathrm{C}\right.$ temperature, $55 \pm 10 \%$ humidity and $12 \mathrm{~h}$ light $-12 \mathrm{~h}$ dark cycles). Diet and water were provided ad libitum. All experimental protocols and procedures were approved by the Institutional Animal Ethical Committee, the National Institute of Nutrition, Hyderabad, India.

\section{Experimental design}

Experimental design is shown in Fig. 1. The present experiment was a completely randomised design, performed in two phases. In phase I (duration 6 months), rats were allocated to four treatments: normal-Ca (0.5\%) diet (NCD) + FFW $(\mathrm{Ca}+\mathrm{F}-/$ control $n$ 12); low-Ca $(0 \cdot 25 \%)$ diet (LCD) + FFW $(\mathrm{Ca}-\mathrm{F}-, n$ 16); NCD +100 ppm F water $(\mathrm{Ca}+\mathrm{F}+, n$ 24); or $\mathrm{LCD}+100 \mathrm{ppm} \mathrm{F}$ water $(\mathrm{Ca}-\mathrm{F}+, n$ 24). After 6 months of this treatment, six animals from the $\mathrm{Ca}+\mathrm{F}-$ treatment (control) and eight animals from all other treatments were killed. In phase II (reversal phase), low $\mathrm{Ca}(\mathrm{Ca}-)$ was replaced by normal $\mathrm{Ca}(\mathrm{Ca}+)$. In some of the fluorotic areas, it is not possible to provide FFW and a nutritional approach is the only option left to mitigate the fluorosis. Keeping that in mind in phase II, treatment groups $\mathrm{Ca}+\mathrm{F}+$ and $\mathrm{Ca}-\mathrm{F}+$ were divided into two subgroups ( $n$ 8) to compare the effect of continuation $v$. discontinuation along with Ca supplementation on reversal of chronic F toxicity. The duration of phase II was 3 months.

\section{Diets}

To simulate the condition of a fluorotic area, cereal-legumebased stock diet (prepared at the National Institute of Nutrition, Hyderabad, India) was fed to rats. The Ca content of the normalCa diet $(\mathrm{Ca}+, 0.5 \%)$ was based on the RDA for rats ${ }^{(33)}$, whereas the Ca content of the low-Ca diet (Ca-, 0.25\%) was selected on

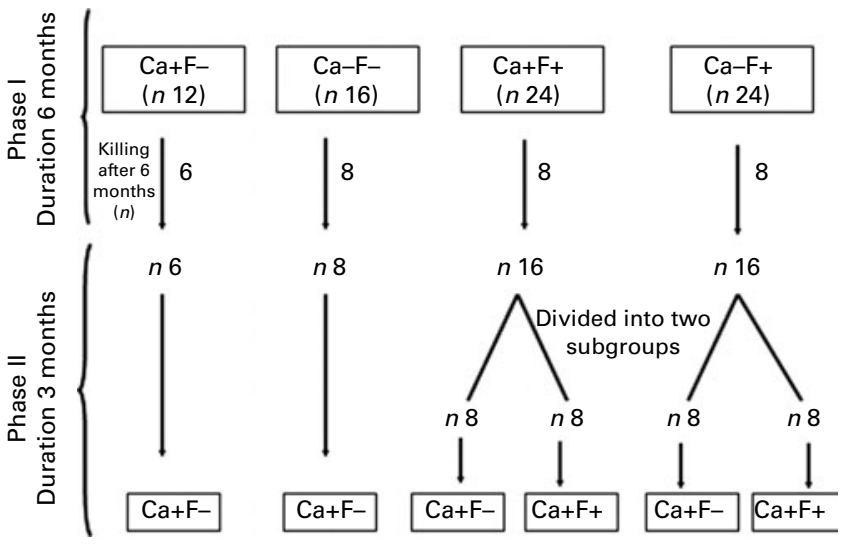

Fig. 1. Animal experiment protocol. $\mathrm{Ca}+$, normal-calcium $(0.5 \%)$ diet; $\mathrm{Ca}-$, low-calcium (0.25\%) diet; F+, 100 parts per million fluoride; F-, fluoridefree water. 
Table 1. Basic composition of diet used for feeding of rats

\begin{tabular}{lc}
\hline Ingredients & Amount (\%) \\
\hline Roasted Bengal gram flour* & 60.0 \\
Wheat flour† & 22.5 \\
Skimmed milk powder $¥$ & 5.0 \\
Casein§ & 4.0 \\
Refined groundnut oil & 4.0 \\
Vitamin mixture\|l & 0.5 \\
Mineral mixture & 4.0 \\
\hline
\end{tabular}

* Fine powder of roasted Bengal gram (Cicer arietinum), a variety of pulse; it provides $22.5 \%$ protein, $5.2 \%$ fat and $58.1 \%$ carbohydrate.

†Fine powder of wheat (Triticum aestivum); it provides $11.8 \%$ protein, $1.5 \%$ fat and $71.2 \%$ carbohydrate.

$\mp$ Commercially available; it provides $38 \%$ protein, $0.1 \%$ fat and $51 \%$ carbohydrate.

$\S$ Milk protein, commercially available.

II Vitamin mixture provided per $\mathrm{kg}$ of diet: DL- $\alpha$-tocopherol acetate, $120 \mathrm{mg}$; menadione, $1.5 \mathrm{mg}$; thiamine, $12 \mathrm{mg}$; riboflavin, $5 \mathrm{mg}$; pyridoxine, $6 \mathrm{mg}$; niacin, $10 \mathrm{mg}$; pantothenic acid (Ca salt), $12 \mathrm{mg}$; cyanocobalamine, $5 \mathrm{mg}$; folic acid, $1 \mathrm{mg}$; paraamino benzoic acid, $100 \mathrm{mg}$; biotin, $400 \mathrm{mg}$; inositol, $100 \mathrm{mg}$; choline chloride, $1000 \mathrm{mg}$

I Mineral mixture provided per kg of diet: $\mathrm{NaCl}, 3.0 \mathrm{~g}$; magnesium sulphate, $2.3 \mathrm{~g}$; ferrous sulphate, $500 \mathrm{mg}$; manganous sulphate, $160 \mathrm{mg}$; potassium iodide, $10 \mathrm{mg}$; zinc sulphate, $22 \mathrm{mg}$; copper sulphate, $19 \mathrm{mg}$; cobalt chloride, $0.12 \mathrm{mg}$; calcium carbonate, $7.12 \mathrm{~g}$ in normal-Ca diet $/ 0.868 \mathrm{~g}$ in low-Ca diet; starch, $26.88 \mathrm{~g}$ in normal-Ca diet $/ 32.43 \mathrm{~g}$ in low-Ca diet.

the basis of the average Ca intake $(335 \mathrm{mg} / \mathrm{d})$ of the Indian population $^{(29)}$, which is almost half of the RDA for $\mathrm{Ca}$ $(600 \mathrm{mg} / \mathrm{d})^{(30)}$. The basic composition was same for both diets (LCD and NCD), except the mineral mixture composition (Table 1). Dietary Ca content was checked by atomic absorption spectrometer (Avanta AAS, GBC Scientific Equipment Limited) to make sure that the diet contained the desired level of $\mathrm{Ca}$.

\section{Water}

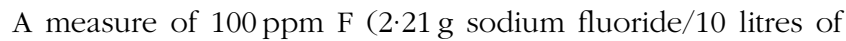
deionised water) was given through drinking water. The average $F$ intake in endemic fluorotic areas is $21 \mathrm{mg} / \mathrm{d}^{(34)}$. To correspond to human intake, rats must be given four to five times $\mathrm{F}^{(35,36)}$. Therefore, $100 \mathrm{ppm} \mathrm{F}$ was used to feed the rats.

\section{Daily food and calcium intake, body weight gain and food efficiency ratio}

Daily food intake (food given - (food left + wastage)) was measured at the interval of $15 \mathrm{~d}$ for three consecutive days and the mean was taken. Daily Ca intake was calculated from diet intake.

Body weight was monitored weekly using a digital balance (Model BL3, Sartorius, maximum capacity-3000 g) and BWG was calculated by deducting baseline body weight from the body weight taken at the particular time interval.

FER (increase in body weight per g of food intake) was calculated by dividing BWG from food consumed in a particular time $\operatorname{period}^{(37)}$.

\section{Blood and urine collection}

Blood was collected by retro-orbital sinus puncture after an overnight fast at the end of phases I and II. Serum was separated and stored at $-80^{\circ} \mathrm{C}$ until further investigation. The $24 \mathrm{~h}$ urine was collected under toluene in separate containers by keeping the rats in metabolism cages for three consecutive days at the end of phases I and II and stored at $4{ }^{\circ} \mathrm{C}$ till further investigation. Urine samples collected at days 1, 2 and 3 were treated as triplicates.

\section{Euthanisation and tissue collection}

Rats were killed by $\mathrm{CO}_{2}$ asphyxiation (phase $\mathrm{I}+$ phase $\mathrm{II}=30+46=76$ ). All vital organs were collected, washed with cold saline, blotted dry and snap-frozen under liquid $\mathrm{N}_{2}$ and stored at $-80^{\circ} \mathrm{C}$ for further use. Femurs were cleaned of adherent tissues and stored at $-80^{\circ} \mathrm{C}$. Proximal small intestine $(5 \mathrm{~cm})$ was collected and immediately washed with cold saline. Duodenal mucosa was scraped, snap-frozen and preserved at $-80^{\circ} \mathrm{C}$ for gene expression studies.

\section{Serum and urinary calcium}

Total serum and urinary Ca excretion were measured by atomic absorption spectrometry ${ }^{(38)}$.

\section{Serum 25-hydroxy-vitamin $D_{3}$ and 1,25-dihydroxy- vitamin $D_{3}$}

Both parameters were analysed by the RIA kit provided by Immune Diagnostics Systems. The manufacturer's protocol was followed. The sensitivity, intra-assay and inter-assay variation of the $25(\mathrm{OH})$ vitamin $\mathrm{D}_{3}$ and $1,25(\mathrm{OH})_{2}$ vitamin $\mathrm{D}_{3}$ assay were $<3 \mathrm{nmol} / 1,5 \cdot 0 \mathrm{pg} / \mathrm{ml} ; 5 \cdot 0,7 \cdot 7 \%$; and $8 \cdot 1,12 \cdot 3 \%$, respectively.

Table 2. Daily food intake, food efficiency ratio (FER) and body weight gain (BWG) in rats fed a normal-calcium ( $0.5 \%)$ diet $(\mathrm{Ca}+\mathrm{F}-$ ), a low-calcium $(0.25 \%)$ diet $(\mathrm{Ca}-\mathrm{F}-)$, the normal-calcium $(0.5 \%)$ diet +100 parts per million $(\mathrm{ppm})$ fluoride $(\mathrm{Ca}+\mathrm{F}+)$ or the low-calcium $(0.25 \%)$ diet $+100 \mathrm{ppm}$ fluoride $(\mathrm{Ca}-\mathrm{F}+)$ for 6 months in phase I of the study

(Mean values with their standard errors)

\begin{tabular}{|c|c|c|c|c|c|c|c|c|c|c|c|}
\hline \multirow{3}{*}{$\begin{array}{l}\text { Treatments ... } \\
n \ldots\end{array}$} & \multicolumn{2}{|c|}{$\mathrm{Ca}+\mathrm{F}-$} & \multicolumn{2}{|c|}{$\mathrm{Ca}-\mathrm{F}-$} & \multicolumn{2}{|c|}{$\mathrm{Ca}+\mathrm{F}+$} & \multicolumn{2}{|c|}{$\mathrm{Ca}-\mathrm{F}+$} & \multirow{2}{*}{\multicolumn{3}{|c|}{$P$}} \\
\hline & \multicolumn{2}{|c|}{12} & \multicolumn{2}{|c|}{16} & \multicolumn{2}{|c|}{24} & \multicolumn{2}{|c|}{24} & & & \\
\hline & Mean & SEM & Mean & SEM & Mean & SEM & Mean & SEM & $\mathrm{Ca}$ & $\mathrm{F}$ & $\mathrm{Ca} \times \mathrm{F}$ \\
\hline Daily food intake (g) & $18 \cdot 0$ & 0.45 & $18 \cdot 0$ & 0.65 & $17 \cdot 5$ & 0.45 & $16 \cdot 8$ & 0.40 & 0.469 & 0.100 & 0.469 \\
\hline FER & $0.133^{\mathrm{a}, \mathrm{b}}$ & 0.003 & $0.136^{a}$ & 0.004 & $0 \cdot 128^{b, c}$ & 0.002 & $0.122^{\mathrm{C}}$ & 0.003 & 0.608 & 0.003 & 0.145 \\
\hline BWG (g) & $360 \cdot 0^{a, b}$ & 6.56 & $373 \cdot 6^{\mathrm{a}}$ & $10 \cdot 71$ & $346 \cdot 3^{\mathrm{b}}$ & 9.04 & $304 \cdot 1^{c}$ & $7 \cdot 21$ & 0.121 & 0.000 & 0.003 \\
\hline
\end{tabular}

${ }^{a, b, c}$ Mean values within a row with unlike superscript letters are significantly different $(P<0.05)$. 


\section{Serum intact parathyroid hormone}

Serum intact parathyroid hormone was assessed using a twosite immune radiometric kit (IDS). The sensitivity, intra-assay variation and inter-assay variation of the parathyroid hormone assay were $1.0 \mathrm{pg} / \mathrm{ml},<4.7$ and $<4.3 \%$, respectively.

\section{Fluoride: urinary and faecal excretion and skeletal deposition}

Urinary $\mathrm{F}$ excretion and faecal $\mathrm{F}$ excretion were measured using an ion-selective electrode (Model EA 940 Orion). Bone $\mathrm{F}$ was determined as previously described ${ }^{(39)}$.

\section{Real-time $P C R$}

Total RNA was isolated from duodenal mucosa using TRIzol reagent (Invitrogen Life Technologies), according to the manufacturer's protocol. Quantitative analysis of the isolated total RNA sample was done using NanoDrop (Thermo Scientific NanoDrop ${ }^{\text {TM }} 1000$ Spectrophotometer; Thermo Fisher Scientific Inc.). Integrity of RNA was confirmed by running RNA samples on $1.5 \%$ denaturing agarose gel. A measure of $3 \mu \mathrm{g}$ of total RNA was reverse transcribed into complementary DNA using the Superscript first-strand synthesis system (Invitrogen Life Technologies). Quantitative PCR was carried out for CASR, $V D R$ and $S 100 G$ using SYBR Premix Ex Taq (Takara Bio, Inc.) in the Stratagene Mx3000P QPCR system (Agilent Technologies). Expressions of $V D R$ and $S 100 G$ genes were quantified using primer sets and PCR conditions reported by Mendoza et al. $^{(40)}$ and Charoenphandhu et al. $^{(41)}$, respectively. For CASR, primers were designed using National center for Biotechnology Information (NCBI) Primer blast. PCR conditions for CASR were as follows: forward primer, $5^{\prime}$-AAGCCATGATATTCGCCATA-3'; reverse primer, 5'-TTCTGGGCAACAAAACTCAA- $3^{\prime}$; annealing temperature, $52^{\circ} \mathrm{C}$; and the amplicon size was $139 \mathrm{bp}$. Expression of target genes was normalised to expression levels of the glyceraldehyde-3-phosphate dehydrogenase $(G A P D H)$ gene $^{(42)}$.

\section{Statistical analysis}

Descriptive statistics were carried out for all parameters. Values are presented as means with their standard errors. For phase I, two-way ANOVA was carried out. $P$ values for the main effect of $\mathrm{Ca}, \mathrm{F}$ and their interaction effect on different parameters are shown in corresponding tables and figure legends. In phase II, one-way ANOVA was carried out followed by the least significant difference post hoc test. The data that did not meet the assumptions of parametric statistics were $\log$ transformed and then subjected to ANOVA. In the present study, data were collected at days 180 (phase I) and 270 (phase II) for every animal (except the animals killed at the end of phase I). To know the significance of the change in the values of different variables at the end of phase II (day 270) with respect to phase I (day 180), or in other words to see the extent of reversibility, the paired $t$ test was applied to the data collected at days 270 and 180 for different

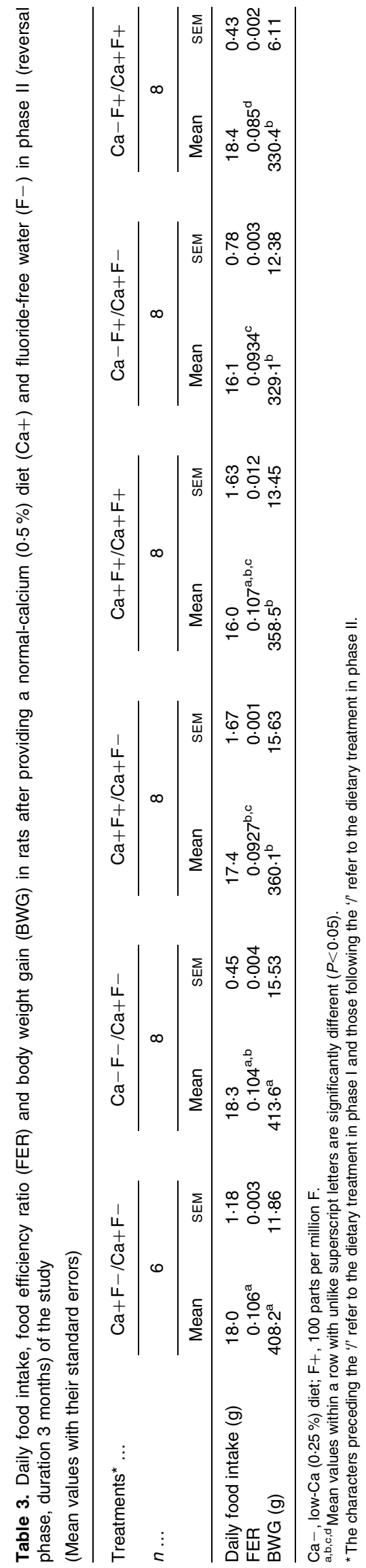


treatment groups. All statistical calculations were carried out using SPSS version 16.0 (SPSS, Inc.) and $P<0.05$ was considered significant for all tests.

\section{Results}

All rats tolerated the experiment without any complications.

\section{Daily food intake, food efficiency ratio and body weight gain}

Daily food intake of groups receiving different treatments was comparable in both phases of the study (Tables 2 and 3). The main effects of $\mathrm{Ca}, \mathrm{F}$ and their interaction effect were not significant for food intake in phase I (Table 2). FER of treatment group $\mathrm{Ca}-\mathrm{F}+$ was significantly lower, as compared with groups receiving $\mathrm{Ca}+\mathrm{F}-$ and $\mathrm{Ca}-\mathrm{F}-$ in phase $\mathrm{I}$, and only $\mathrm{F}$ had a significant effect on FER (Table 2). In phase II, FER of treatment groups $\mathrm{Ca}-\mathrm{F}+/ \mathrm{Ca}+\mathrm{F}-$ and $\mathrm{Ca}-\mathrm{F}+/ \mathrm{Ca}+\mathrm{F}+$ was significantly lower, as compared with $\mathrm{Ca}+\mathrm{F}-/ \mathrm{Ca}+\mathrm{F}-(P=0 \cdot 010), \mathrm{Ca}-\mathrm{F}-/$ $\mathrm{Ca}+\mathrm{F}-(P=0.036)$ and $\mathrm{Ca}+\mathrm{F}-/ \mathrm{Ca}+\mathrm{F}-(P=0.003), \mathrm{Ca}-\mathrm{F}-/$ $\mathrm{Ca}+\mathrm{F}-(P=0.002), \mathrm{Ca}+\mathrm{F}+/ \mathrm{Ca}+\mathrm{F}-(P=0.044), \mathrm{Ca}+\mathrm{F}+/$ $\mathrm{Ca}+\mathrm{F}+(P=0 \cdot 021)$ and $\mathrm{Ca}-\mathrm{F}+/ \mathrm{Ca}+\mathrm{F}-(P=0 \cdot 029)$, respectively (Table 3 ). BWG of treatment group $\mathrm{Ca}-\mathrm{F}+$ was significantly lower, as compared with all groups in phase I. The main effect of $\mathrm{F}$ as well as the interaction effect of $\mathrm{Ca}$ and $\mathrm{F}$ affected BWG (Table 2). In phase II also, groups receiving $\mathrm{Ca}-\mathrm{F}+/ \mathrm{Ca}+\mathrm{F}-$ and $\mathrm{Ca}-\mathrm{F}+/ \mathrm{Ca}+\mathrm{F}+$ had significantly lower
BWG, as compared with groups $\mathrm{Ca}+\mathrm{F}-/ \mathrm{Ca}+\mathrm{F}-(P=0.001)$ and $\mathrm{Ca}-\mathrm{F}-/ \mathrm{Ca}+\mathrm{F}-(P=0 \cdot 001)$ (Table 3$)$.

\section{Fluoride: urinary and faecal excretion and skeletal deposition}

In phase I, urinary $\mathrm{F}$ excretion of treatment group $\mathrm{Ca}-\mathrm{F}+$ was significantly higher and faecal $\mathrm{F}$ excretion was significantly lower, as compared with the $\mathrm{Ca}+\mathrm{F}+$ treatment group (Fig. 2(A)). Bone F deposition was significantly higher in treatment group $\mathrm{Ca}-\mathrm{F}+$, as compared with the $\mathrm{Ca}+\mathrm{F}+$ treatment group (Fig. 2(B)). The main effects of $\mathrm{Ca}$ and $\mathrm{F}$ and their interaction effect were significant for all the three parameters. In phase II, urinary $\mathrm{F}$ excretion of the $\mathrm{Ca}-\mathrm{F}+/ \mathrm{Ca}+\mathrm{F}-$ group was significantly higher $(P=0.002)$, as compared with group $\mathrm{Ca}+\mathrm{F}+/ \mathrm{Ca}+\mathrm{F}-($ Fig. $2(\mathrm{C})$ ). Groups receiving $\mathrm{Ca}+\mathrm{F}+/$ $\mathrm{Ca}+\mathrm{F}+$ and $\mathrm{Ca}-\mathrm{F}+/ \mathrm{Ca}+\mathrm{F}+$ treatments showed significantly higher bone $\mathrm{F}$ deposition, as compared with treatment groups $\mathrm{Ca}+\mathrm{F}+/ \mathrm{Ca}+\mathrm{F}-\quad(P=0.001)$ and $\mathrm{Ca}-\mathrm{F}+/ \mathrm{Ca}+\mathrm{F}-$ $(P=0.002)$, respectively. Further, bone $\mathrm{F}$ deposition in treatment group $\mathrm{Ca}-\mathrm{F}+/ \mathrm{Ca}+\mathrm{F}-$ was significantly higher $(P=0.001)$ than in the $\mathrm{Ca}+\mathrm{F}+/ \mathrm{Ca}+\mathrm{F}-$ group (Fig. 2(D)).

\section{Calcium homeostasis}

Daily calcium intake, serum calcium and urinary calcium excretion. In phase I, daily $\mathrm{Ca}$ intake of treatment groups $\mathrm{Ca}-\mathrm{F}-$ and $\mathrm{Ca}-\mathrm{F}+$ was significantly lower, as compared
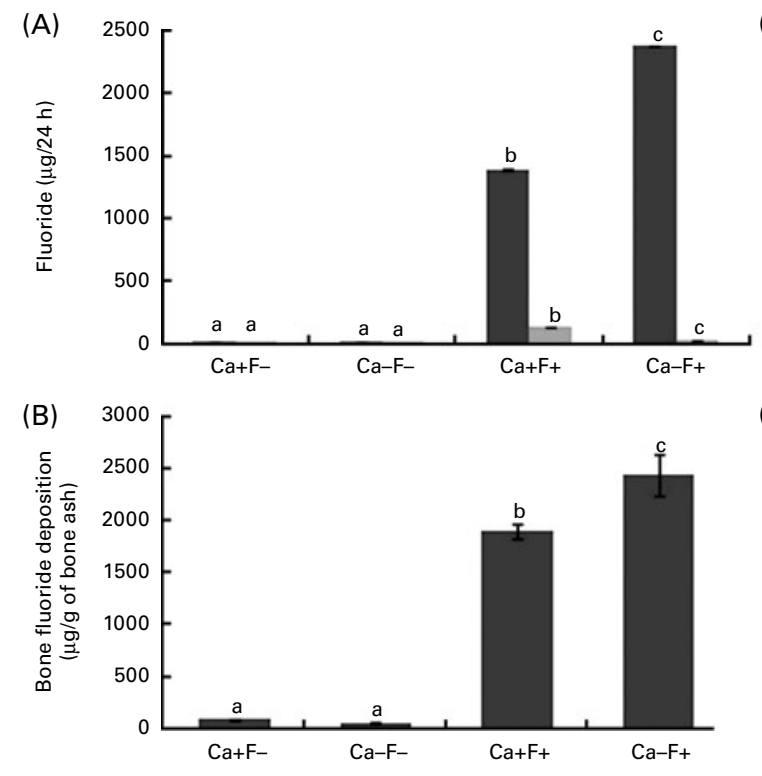

(C)

(D)
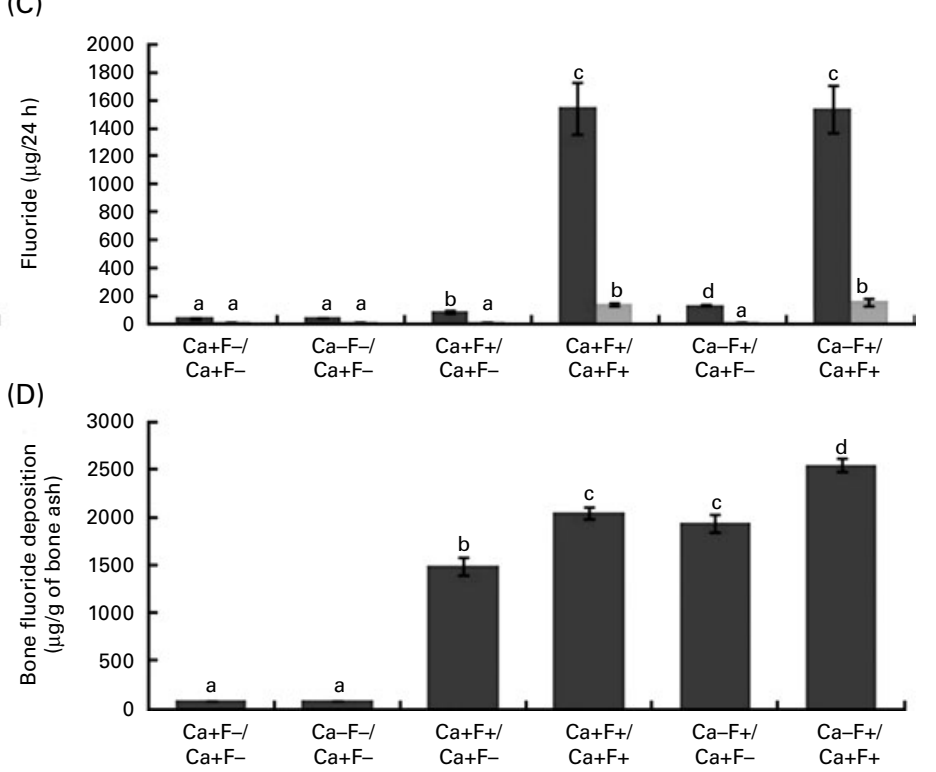

Fig. 2. (A) Urinary ( $\square$ ) and faecal (ם) fluoride excretion in rats fed a normal-calcium $(0.5 \%)$ diet $(\mathrm{Ca}+\mathrm{F}-)$, a low-calcium $(0.25 \%)$ diet $(\mathrm{Ca}-\mathrm{F}-)$, the normalcalcium $(0.5 \%)$ diet +100 parts per million $(\mathrm{ppm})$ fluoride $(\mathrm{Ca}+\mathrm{F}+)$ or the low-calcium $(0.25 \%)$ diet $+100 \mathrm{ppm}$ fluoride $(\mathrm{Ca}-\mathrm{F}+)$ for 6 months in phase I. $P$ for main effect of calcium, main effect of fluoride and calcium $\times$ fluoride on urinary fluoride excretion and faecal fluoride excretion $=0.001$. (B) Bone fluoride deposition in rats fed the normal-calcium $(0.5 \%)$ diet $(\mathrm{Ca}+\mathrm{F}-)$, the low-calcium $(0.25 \%)$ diet $(\mathrm{Ca}-\mathrm{F}-)$, the normal calcium $(0.5 \%)$ diet $+100 \mathrm{ppm}$ fluoride $(\mathrm{Ca}+\mathrm{F}+)$ or the low-calcium $(0.25 \%)$ diet $+100 \mathrm{ppm}$ fluoride $(\mathrm{Ca}-\mathrm{F}+)$ for 6 months in phase I. There were significant main effects for calcium $(P=0.028)$, fluoride $(P=0.001)$ and calcium $\times$ fluoride $(P=0.014)$. (C) Urinary and faecal fluoride excretion and (D) bone fluoride deposition in rats after providing the normal-calcium $(0.5 \%)$ diet and fluoride-free water treatment in phase II (reversal phase, duration 3 months) of the study. In (C) and (D), the characters preceding the '" on the $x$ axis refer to the dietary treatment in phase I and the characters following the ' $\%$ refer to the dietary treatment in phase II. Values are means, with their standard errors represented by vertical bars. Phase $\mathrm{I}, \mathrm{Ca}+\mathrm{F}-(n 12), \mathrm{Ca}-\mathrm{F}-(n 16), \mathrm{Ca}+\mathrm{F}+$ and $\mathrm{Ca}-\mathrm{F}+(n$ 24); phase II, $n 8$ except $\mathrm{Ca}+\mathrm{F}-/ \mathrm{Ca}+\mathrm{F}-$ treatment group $(n 6) .{ }^{\mathrm{a}, \mathrm{b}, \mathrm{c}, \mathrm{d}}$ Mean values with unlike letters are significantly different $(P<0.05)$. 
Table 4. Daily calcium intake, serum calcium and urinary calcium excretion in rats fed a normal-calcium $(0.5 \%)$ diet $(\mathrm{Ca}+\mathrm{F}-)$ a low-calcium $(0.25 \%)$ diet $(\mathrm{Ca}-\mathrm{F}-)$, the normal-calcium $(0.5 \%)$ diet +100 parts per million $(\mathrm{ppm})$ fluoride $(\mathrm{Ca}+\mathrm{F}+)$ or the low-calcium $(0.25 \%)$ diet $+100 \mathrm{ppm}$ fluoride $(\mathrm{Ca}-\mathrm{F}+)$ for 6 months in phase I of the study

(Mean values with their standard errors)

\begin{tabular}{|c|c|c|c|c|c|c|c|c|c|c|c|}
\hline \multirow{3}{*}{$\begin{array}{l}\text { Treatments ... } \\
n \ldots\end{array}$} & \multirow{2}{*}{\multicolumn{2}{|c|}{$\frac{\mathrm{Ca}+\mathrm{F}-}{12}$}} & \multirow{2}{*}{\multicolumn{2}{|c|}{$\frac{\mathrm{Ca}-\mathrm{F}-}{16}$}} & \multirow{2}{*}{\multicolumn{2}{|c|}{$\frac{\mathrm{Ca}+\mathrm{F}+}{24}$}} & \multirow{2}{*}{\multicolumn{2}{|c|}{$\frac{\mathrm{Ca}-\mathrm{F}+}{24}$}} & \multirow{2}{*}{\multicolumn{3}{|c|}{$P$}} \\
\hline & & & & & & & & & & & \\
\hline & Mean & SEM & Mean & SEM & Mean & SEM & Mean & SEM & $\mathrm{Ca}$ & $\mathrm{F}$ & $\mathrm{Ca} \times \mathrm{F}$ \\
\hline Daily Ca intake $(\mathrm{mg} / \mathrm{d})$ & $95 \cdot 8^{a}$ & 1.42 & $47 \cdot 8^{\mathrm{b}}$ & $1 \cdot 29$ & $95 \cdot 8^{a}$ & 2.91 & $45 \cdot 2^{b}$ & 1.98 & 0.000 & 0.594 & 0.605 \\
\hline Serum Ca $(\mathrm{mmol} / \mathrm{l})$ & $2 \cdot 4^{\mathrm{a}}$ & 0.02 & $1.9^{\mathrm{b}}$ & 0.04 & $2 \cdot 2^{\mathrm{C}}$ & 0.02 & $1.8^{\mathrm{d}}$ & 0.02 & 0.000 & 0.000 & 0.000 \\
\hline Urinary $\mathrm{Ca}(\mathrm{mmol} / \mathrm{l})$ & $0.3^{\mathrm{a}}$ & 0.07 & $0.2^{a, b}$ & 0.01 & $0.2^{a, b}$ & 0.03 & $0.2^{b}$ & 0.02 & 0.043 & 0.140 & 0.616 \\
\hline
\end{tabular}

a,b,c,d Mean values within a row with unlike superscript letters are significantly different $(P<0.05)$.

with the treatment groups $\mathrm{Ca}+\mathrm{F}-$ and $\mathrm{Ca}+\mathrm{F}+$ (Table 4). Serum $\mathrm{Ca}$ of treatment groups $\mathrm{Ca}-\mathrm{F}-$ and $\mathrm{Ca}-\mathrm{F}+$ was significantly lower, as compared with the treatment groups $\mathrm{Ca}+\mathrm{F}-$ and $\mathrm{Ca}+\mathrm{F}+$. Treatment group $\mathrm{Ca}+\mathrm{F}+$ also showed lower serum $\mathrm{Ca}$, as compared with the treatment group $\mathrm{Ca}+\mathrm{F}-$ (Table 4). Urinary $\mathrm{Ca}$ excretion of the treatment group $\mathrm{Ca}-\mathrm{F}+$ was significantly lower, as compared with the treatment group $\mathrm{Ca}+\mathrm{F}-$ (Table 4 ). For daily $\mathrm{Ca}$ intake and urinary $\mathrm{Ca}$ excretion, only the main effect of $\mathrm{Ca}$ was significant. However, main as well as interaction effects of both factors significantly affected serum $\mathrm{Ca}$ (Table 4). In phase II, treatment groups $\mathrm{Ca}-\mathrm{F}+/ \mathrm{Ca}+\mathrm{F}-$ and $\mathrm{Ca}-\mathrm{F}+/ \mathrm{Ca}+\mathrm{F}+$ showed significantly lower serum $\mathrm{Ca}$, as compared with the treatment groups $\mathrm{Ca}+\mathrm{F}-/ \mathrm{Ca}+\mathrm{F}-(P=0.002)$ and $\mathrm{Ca}+\mathrm{F}-/$ $\mathrm{Ca}+\mathrm{F}-(P=0.016), \mathrm{Ca}-\mathrm{F}-/ \mathrm{Ca}+\mathrm{F}-(P=0.004), \mathrm{Ca}+\mathrm{F}+/$ $\mathrm{Ca}+\mathrm{F}-\quad(P=0.004), \quad \mathrm{Ca}+\mathrm{F}+/ \mathrm{Ca}+\mathrm{F}+\quad(P=0.004) \quad$ and $\mathrm{Ca}-\mathrm{F}+/ \mathrm{Ca}+\mathrm{F}-(P=0.004)$, respectively (Table 5$)$.

Serum parathyroid hormone, 25-hydroxy-vitamin $D_{3}$ and 1,25-dihydroxy-vitamin $D_{3}$. In phase I, serum $25(\mathrm{OH})$ vitamin $\mathrm{D}_{3}$ of treatment group $\mathrm{Ca}-\mathrm{F}+$ was significantly lower, as compared with the treatment groups $\mathrm{Ca}+\mathrm{F}-$ and $\mathrm{Ca}+\mathrm{F}+$, whereas serum $25(\mathrm{OH})$ vitamin $\mathrm{D}_{3}$ of treatment group $\mathrm{Ca}-\mathrm{F}-$ was significantly lower, as compared with the treatment group $\mathrm{Ca}+\mathrm{F}+$ only (Table 6). As expected, treatment groups $\mathrm{Ca}-\mathrm{F}-$ and $\mathrm{Ca}-\mathrm{F}+$ had significantly higher serum $1,25(\mathrm{OH})_{2}$ vitamin $\mathrm{D}_{3}$, as compared with the treatment groups $\mathrm{Ca}+\mathrm{F}-$ and $\mathrm{Ca}+\mathrm{F}+$. Further, treatment group $\mathrm{Ca}-\mathrm{F}+$ showed significantly increased $1,25(\mathrm{OH})_{2}$ vita- min $\mathrm{D}_{3}$, as compared with the treatment group $\mathrm{Ca}-\mathrm{F}-$ (Table 6). Ca treatment significantly affected serum $25(\mathrm{OH})$ vitamin $\mathrm{D}_{3}$. For serum $1,25(\mathrm{OH})_{2}$ vitamin $\mathrm{D}_{3}$, the main as well as interaction effects of both factors were significant (Table 6). In phase II of the study, treatment group $\mathrm{Ca}-\mathrm{F}+/ \mathrm{Ca}+\mathrm{F}+$ showed significantly higher $(P=0.043)$ serum parathyroid hormone, as compared with the group receiving $\mathrm{Ca}+\mathrm{F}+/ \mathrm{Ca}+\mathrm{F}+$ treatment (Table 7).

\section{Gene expression studies}

In phase I of the study, expression levels of CASR and VDR genes showed a significant increase in treatment groups $\mathrm{Ca}-\mathrm{F}-, \mathrm{Ca}+\mathrm{F}+$ and $\mathrm{Ca}-\mathrm{F}+$, as compared with the treatment group $\mathrm{Ca}+\mathrm{F}-$ (Fig. 3(A) and (B)). Further, treatment group $\mathrm{Ca}-\mathrm{F}+$ showed a significantly higher expression of $C A S R$, as compared with groups receiving $\mathrm{Ca}-\mathrm{F}-$ and $\mathrm{Ca}+\mathrm{F}+$. F-treated groups $(\mathrm{Ca}+\mathrm{F}+$ and $\mathrm{Ca}-\mathrm{F}+)$ exhibited significantly higher $V D R$ expression, as compared with the group receiving $\mathrm{Ca}-\mathrm{F}-$. Expression of $S 100 \mathrm{G}$ was significantly higher in treatment group $\mathrm{Ca}-\mathrm{F}-$, as compared with $\mathrm{Ca}+\mathrm{F}-$ and $\mathrm{Ca}+\mathrm{F}+$. Treatment group $\mathrm{Ca}-\mathrm{F}+$ showed significantly higher expression of $\$ 100 G$, as compared with all other groups (Fig. 3(C)). The main effects of both factors (Ca and F) were significant for expression of CASR and $V D R$; however, their interaction effect was not significant. For $S 100 G$ expression, $\mathrm{F}$ was not a significant factor, though the main effect of $\mathrm{Ca}$ and the interaction effect of $\mathrm{Ca}$ and $\mathrm{F}$ were significant.

Table 5. Daily calcium intake, serum calcium and urinary calcium excretion in rats after providing a normal-calcium ( $0.5 \%)$ diet $(\mathrm{Ca}+)$ and fluoride-free water $(\mathrm{F}-)$ in phase II (reversal phase, duration 3 months) of the study

(Mean values with their standard errors)

\begin{tabular}{|c|c|c|c|c|c|c|c|c|c|c|c|c|}
\hline Treatments* $\ldots$ & \multicolumn{2}{|c|}{$\begin{array}{l}\mathrm{Ca}+\mathrm{F}-/ \\
\mathrm{Ca}+\mathrm{F}-\end{array}$} & \multicolumn{2}{|c|}{$\begin{array}{l}\mathrm{Ca}-\mathrm{F}-/ \\
\mathrm{Ca}+\mathrm{F}-\end{array}$} & \multicolumn{2}{|c|}{$\begin{array}{l}\mathrm{Ca}+\mathrm{F}+1 \\
\mathrm{Ca}+\mathrm{F}-\end{array}$} & \multicolumn{2}{|c|}{$\begin{array}{l}\mathrm{Ca}+\mathrm{F}+1 \\
\mathrm{Ca}+\mathrm{F}+\end{array}$} & \multicolumn{2}{|c|}{$\begin{array}{l}\mathrm{Ca}-\mathrm{F}+1 \\
\mathrm{Ca}+\mathrm{F}-\end{array}$} & \multicolumn{2}{|c|}{$\begin{array}{l}\mathrm{Ca}-\mathrm{F}+/ \\
\mathrm{Ca}+\mathrm{F}+\end{array}$} \\
\hline \multirow[t]{2}{*}{$n \ldots$} & \multicolumn{2}{|c|}{6} & \multicolumn{2}{|c|}{8} & \multicolumn{2}{|c|}{8} & \multicolumn{2}{|c|}{8} & \multicolumn{2}{|c|}{8} & \multicolumn{2}{|c|}{8} \\
\hline & Mean & SEM & Mean & SEM & Mean & SEM & Mean & SEM & Mean & SEM & Mean & SEM \\
\hline Daily Ca intake (mg/d) & $90 \cdot 0^{a}$ & 5.92 & $91 \cdot 4^{\mathrm{a}}$ & $2 \cdot 25$ & $86 \cdot 9^{a}$ & $8 \cdot 37$ & $80 \cdot 0^{\mathrm{a}}$ & $8 \cdot 18$ & $80 \cdot 6^{a}$ & $3 \cdot 89$ & $91 \cdot 8^{a}$ & $2 \cdot 16$ \\
\hline Serum Ca $(\mathrm{mmol} / \mathrm{l})$ & $2 \cdot 4^{\mathrm{a}}$ & 0.03 & $2 \cdot 1^{\mathrm{b}}$ & 0.02 & $2 \cdot 3^{c}$ & 0.03 & $2 \cdot 2^{\mathrm{c}}$ & 0.02 & $2 \cdot 1^{\mathrm{b}, \mathrm{c}}$ & 0.02 & $2 \cdot 0^{\mathrm{d}}$ & 0.02 \\
\hline Urinary $\mathrm{Ca}(\mathrm{mmol} / \mathrm{l})$ & $0 \cdot 2^{a, b}$ & 0.02 & $0 \cdot 2^{a, b}$ & 0.05 & $0 \cdot 2^{a, b}$ & 0.05 & $0 \cdot 2^{a, b}$ & 0.02 & $0 \cdot 2^{b}$ & 0.04 & $0 \cdot 1^{\mathrm{a}}$ & 0.02 \\
\hline
\end{tabular}

$\mathrm{Ca}-$, low $\mathrm{Ca}(0.25 \%)$ diet; $\mathrm{F}+, 100$ parts per million $\mathrm{F}$

$\mathrm{a}, \mathrm{b}, \mathrm{c}, \mathrm{d}$ Mean values within a row with unlike superscript letters are significantly different $(P<005)$

* The characters preceding the '" refer to the dietary treatment in phase I and those following the ' 
Table 6. Serum 25-hydroxy-vitamin $D_{3}$, parathyroid hormone and 1,25-dihydroxy-vitamin $D_{3}$ in rats fed a normal-calcium $(0.5 \%)$ diet $(C a+F-)$, a low-calcium $(0.25 \%)$ diet $(\mathrm{Ca}-\mathrm{F}-)$, the normal-calcium $(0.5 \%)$ diet +100 parts per million $(\mathrm{ppm})$ fluoride $(\mathrm{Ca}+\mathrm{F}+)$ or the low-calcium $(0.25 \%)$ diet $+100 \mathrm{ppm}$ fluoride $(\mathrm{Ca}-\mathrm{F}+)$ for 6 months in phase I of the study

(Mean values with their standard errors)

\begin{tabular}{|c|c|c|c|c|c|c|c|c|c|c|c|}
\hline \multirow{3}{*}{$\begin{array}{l}\text { Treatments... } \\
n \ldots\end{array}$} & \multirow{2}{*}{\multicolumn{2}{|c|}{$\frac{\mathrm{Ca}+\mathrm{F}-}{12}$}} & \multirow{2}{*}{\multicolumn{2}{|c|}{$\frac{\mathrm{Ca}-\mathrm{F}-}{16}$}} & \multirow{2}{*}{\multicolumn{2}{|c|}{$\frac{\mathrm{Ca}+\mathrm{F}+}{24}$}} & \multirow{2}{*}{\multicolumn{2}{|c|}{$\frac{\mathrm{Ca}-\mathrm{F}+}{24}$}} & \multirow{2}{*}{\multicolumn{3}{|c|}{$P$}} \\
\hline & & & & & & & & & & & \\
\hline & Mean & SEM & Mean & SEM & Mean & SEM & Mean & SEM & $\mathrm{Ca}$ & $\mathrm{F}$ & $\mathrm{Ca} \times \mathrm{F}$ \\
\hline 25-Hydroxy-vitamin $D_{3}(\mathrm{nmol} / \mathrm{l})$ & $30 \cdot 6^{\mathrm{a}, \mathrm{b}}$ & 1.27 & $27 \cdot 2^{\mathrm{b}, \mathrm{c}}$ & 1.26 & $31 \cdot 5^{\mathrm{a}}$ & 0.90 & $26 \cdot 7^{\mathrm{c}}$ & $1 \cdot 23$ & 0.003 & 0.896 & 0.430 \\
\hline Parathyroid hormone (pmol/l) & $57 \cdot 6$ & $25 \cdot 51$ & $88 \cdot 3$ & 38.85 & $86 \cdot 0$ & $22 \cdot 52$ & $116 \cdot 9$ & $50 \cdot 3$ & 0.431 & 0.466 & 0.997 \\
\hline 1,25-Dihydroxy-vitamin $\mathrm{D}_{3}(\mathrm{pmol} / \mathrm{l})$ & $49 \cdot 4^{a}$ & $6 \cdot 14$ & $80 \cdot 6^{\mathrm{b}}$ & 4.65 & $53 \cdot 8^{a}$ & $5 \cdot 33$ & $123 \cdot 5^{\mathrm{c}}$ & $7 \cdot 80$ & 0.00 & 0.001 & 0.005 \\
\hline
\end{tabular}

${ }^{a, b, c}$ Mean values within a row with unlike superscript letters are significantly different $(P<0.05)$

In phase II, treatment groups $\mathrm{Ca}-\mathrm{F}+/ \mathrm{Ca}+\mathrm{F}-$ and $\mathrm{Ca}-\mathrm{F}+/$ $\mathrm{Ca}+\mathrm{F}+$ showed significantly higher $C A S R$ expression, as compared with treatment groups $\mathrm{Ca}+\mathrm{F}+/ \mathrm{Ca}+\mathrm{F}-(P=0.020)$, $\mathrm{Ca}+\mathrm{F}+/ \mathrm{Ca}+\mathrm{F}+(P=0 \cdot 012)$ and $\mathrm{Ca}+\mathrm{F}+/ \mathrm{Ca}+\mathrm{F}+(P=0 \cdot 030)$, respectively (Fig. 3(D)). VDR expression of all groups was comparable except for treatment group $\mathrm{Ca}-\mathrm{F}-/ \mathrm{Ca}+\mathrm{F}-$, which was significantly higher, as compared with groups receiving $\mathrm{Ca}+\mathrm{F}-/$ $\mathrm{Ca}+\mathrm{F}-(P=0.018), \mathrm{Ca}+\mathrm{F}+/ \mathrm{Ca}+\mathrm{F}-(P=0.006)$ and $\mathrm{Ca}+\mathrm{F}+/$ $\mathrm{Ca}+\mathrm{F}+(P=0.043)$ (Fig. 3(E)). Treatment groups $\mathrm{Ca}+\mathrm{F}+/$ $\mathrm{Ca}+\mathrm{F}+$ and $\mathrm{Ca}-\mathrm{F}+/ \mathrm{Ca}+\mathrm{F}+$ showed significantly lower expression of $\mathrm{S100G}$, as compared with $\mathrm{Ca}+\mathrm{F}+/ \mathrm{Ca}+\mathrm{F}-$ $(P=0.002$ for $\mathrm{Ca}+\mathrm{F}+/ \mathrm{Ca}+\mathrm{F}+$ and $P=0.018$ for $\mathrm{Ca}-\mathrm{F}+$ ) $\mathrm{Ca}+\mathrm{F}+)$ (Fig. 3(F)).

\section{Discussion}

Fluorosis becomes aggravated in the presence of inadequate $\mathrm{Ca}$ nutrition $^{(11,27,28)}$. The present study explored adverse effects of chronic F toxicity on FER, BWG, body composition, $\mathrm{Ca}$ homeostasis and expression of genes involved in $\mathrm{Ca}$ homeostasis in the presence of adequate or inadequate $\mathrm{Ca}$ as well as amelioration of the same by providing FFW and adequate $\mathrm{Ca}$. Data collected in the study indicated that $\mathrm{F}$ exhibited a negative impact on BWG in the presence of inadequate $\mathrm{Ca}$. Reduced FER in the treatment group $\mathrm{Ca}-\mathrm{F}+$ indicated interference of $\mathrm{F}$ with digestion and proper utilisation of food. Decrease in BWG due to $\mathrm{F}$ toxicity in the presence of $\mathrm{Ca}$ malnutrition has also been reported previously ${ }^{(7,43)}$. In phase II, no effect of providing FFW or NCD was observed on BWG.
Significantly higher FER of the treatment group $\mathrm{Ca}-\mathrm{F}+/$ $\mathrm{Ca}+\mathrm{F}-$, as compared with group $\mathrm{Ca}-\mathrm{F}+/ \mathrm{Ca}+\mathrm{F}+$ (difference of means, $0 \cdot 011$; SEM, $0 \cdot 0016 ; P=0 \cdot 001$ ), indicated towards the role of FFW for efficient utilisation of food.

In phase $\mathrm{I}$, higher urinary $\mathrm{F}$ excretion and bone $\mathrm{F}$ deposition in treatment group $\mathrm{Ca}-\mathrm{F}+$ with respect to treatment group $\mathrm{Ca}+\mathrm{F}+$ shows that $\mathrm{F}$ toxicity was worse in the presence of inadequate $\mathrm{Ca}$. However, excretion of $\mathrm{F}$ through faeces was higher in the presence of adequate $\mathrm{Ca}$, due to the removal of $\mathrm{F}$ in the form of calcium fluoride from the body ${ }^{(23,24)}$. All the findings of the present study are in agreement with an earlier study ${ }^{(7)}$ carried out in rats (fed 0.125 or $0.25 \% \mathrm{Ca}$ and 5,15 or $50 \mathrm{ppm} \mathrm{F}$ ), which showed that with reduction in dietary $\mathrm{Ca}$, faecal $\mathrm{F}$ excretion and the absorption as well as tissue retention of $\mathrm{F}$ increased. In phase II, after receiving $\mathrm{NCD}+\mathrm{FFW}$, treatment group $\mathrm{Ca}-\mathrm{F}+/ \mathrm{Ca}+\mathrm{F}-$ exhibited higher urinary clearance of $\mathrm{F}$, as compared with treatment group $\mathrm{Ca}+\mathrm{F}+/ \mathrm{Ca}+\mathrm{F}-$, which suggests that feeding an adequate-Ca diet with FFW can mitigate the additive adverse effects of chronic F and LCD treatment. However, still higher bone $\mathrm{F}$ deposition in treatment group $\mathrm{Ca}-\mathrm{F}+/ \mathrm{Ca}+\mathrm{F}-$, as compared with the treatment group $\mathrm{Ca}+\mathrm{F}+/ \mathrm{Ca}+\mathrm{F}-$, implies that a longer duration might be needed for complete reversal.

Consumption of the LCD produced hypocalcaemia in treatment groups $\mathrm{Ca}-\mathrm{F}-$ and $\mathrm{Ca}-\mathrm{F}+$, as shown by serum $\mathrm{Ca}$ levels and further supported by low urinary $\mathrm{Ca}$ excretion (only in treatment group $\mathrm{Ca}-\mathrm{F}+$ ). In addition, decreased serum $\mathrm{Ca}$ in treatment group $\mathrm{Ca}+\mathrm{F}+$, as compared with $\mathrm{Ca}+\mathrm{F}-$ (FFW-treated counterpart), was also observed. Due

Table 7. Serum 25-hydroxy-vitamin $D_{3}$, parathyroid hormone and 1,25-dihydroxy-vitamin $D_{3}$ in rats after providing a normal-calcium ( $\left.0.5 \%\right)$ diet $(C a+)$ and fluoride-free water ( $\mathrm{F}-$ ) in phase II (reversal phase, duration 3 months) of the study

(Mean values with their standard errors)

\begin{tabular}{|c|c|c|c|c|c|c|c|c|c|c|c|c|}
\hline \multirow{3}{*}{$\begin{array}{l}\text { Treatments }{ }^{*} \ldots \\
\text { n... }\end{array}$} & \multirow{2}{*}{\multicolumn{2}{|c|}{$\frac{\mathrm{Ca}+\mathrm{F}-/ \mathrm{Ca}+\mathrm{F}-}{6}$}} & \multirow{2}{*}{\multicolumn{2}{|c|}{$\begin{array}{c}\mathrm{Ca}-\mathrm{F}-/ \\
\mathrm{Ca}+\mathrm{F}-\end{array}$}} & \multirow{2}{*}{\multicolumn{2}{|c|}{$\begin{array}{c}\begin{array}{l}\mathrm{Ca}+\mathrm{F}+1 \\
\mathrm{Ca}+\mathrm{F}-\end{array} \\
8\end{array}$}} & \multirow{2}{*}{\multicolumn{2}{|c|}{$\begin{array}{c}\mathrm{Ca}+\mathrm{F}+/ \\
\mathrm{Ca}+\mathrm{F}+ \\
8\end{array}$}} & \multirow{2}{*}{\multicolumn{2}{|c|}{$\begin{array}{c}\mathrm{Ca}-\mathrm{F}+/ \\
\mathrm{Ca}+\mathrm{F}- \\
8\end{array}$}} & \multirow{2}{*}{\multicolumn{2}{|c|}{$\begin{array}{c}\mathrm{Ca}-\mathrm{F}+/ \\
\mathrm{Ca}+\mathrm{F}+ \\
8\end{array}$}} \\
\hline & & & & & & & & & & & & \\
\hline & Mean & SEM & Mean & SEM & Mean & $\overline{\text { SEM }}$ & Mean & $\overline{\text { SEM }}$ & Mean & SEM & Mean & $\overline{\text { SEM }}$ \\
\hline \multirow{3}{*}{$\begin{array}{l}\text { 25-Hydroxy-vitamin } \mathrm{D}_{3}(\mathrm{nmol} / \mathrm{l}) \\
\text { Parathyroid hormone }(\mathrm{pmol} / \mathrm{l}) \\
\text { 1,25-Dihydroxy-vitamin } \mathrm{D}_{3}(\mathrm{pmol} / \mathrm{l})\end{array}$} & $25 \cdot 8^{\mathrm{a}}$ & 3.32 & $24.5^{a}$ & 2.54 & $17 \cdot 5^{\mathrm{b}}$ & 1.21 & $26 \cdot 3^{a}$ & 1.76 & $24 \cdot 3^{a, b}$ & 2.88 & $26 \cdot 0^{\mathrm{a}}$ & 0.73 \\
\hline & $44 \cdot 0^{a, b}$ & $174 \cdot 4$ & $54 \cdot 4^{\mathrm{a}, \mathrm{b}}$ & $12 \cdot 15$ & $55 \cdot 1^{a, b}$ & 8.73 & $52.9^{a}$ & $6 \cdot 11$ & $61 \cdot 0^{a, b}$ & 3.25 & $69 \cdot 8^{\mathrm{b}}$ & 6.49 \\
\hline & $30 \cdot 7$ & 27.90 & 29.9 & 3.64 & $31 \cdot 2$ & 2.91 & $27 \cdot 6$ & $2 \cdot 70$ & 28.9 & $3 \cdot 22$ & 45.5 & $10 \cdot 35$ \\
\hline
\end{tabular}

$\mathrm{Ca}-$, low $\mathrm{Ca}(0.25 \%)$ diet; $\mathrm{F}+, 100$ parts per million $\mathrm{F}$.

a,b,c Mean values within a row with unlike superscript letters are significantly different $(P<0.05)$.

* The characters preceding the ' $"$ refer to the dietary treatment in phase I and those following the ' $/$ refer to the dietary treatment in phase II. 

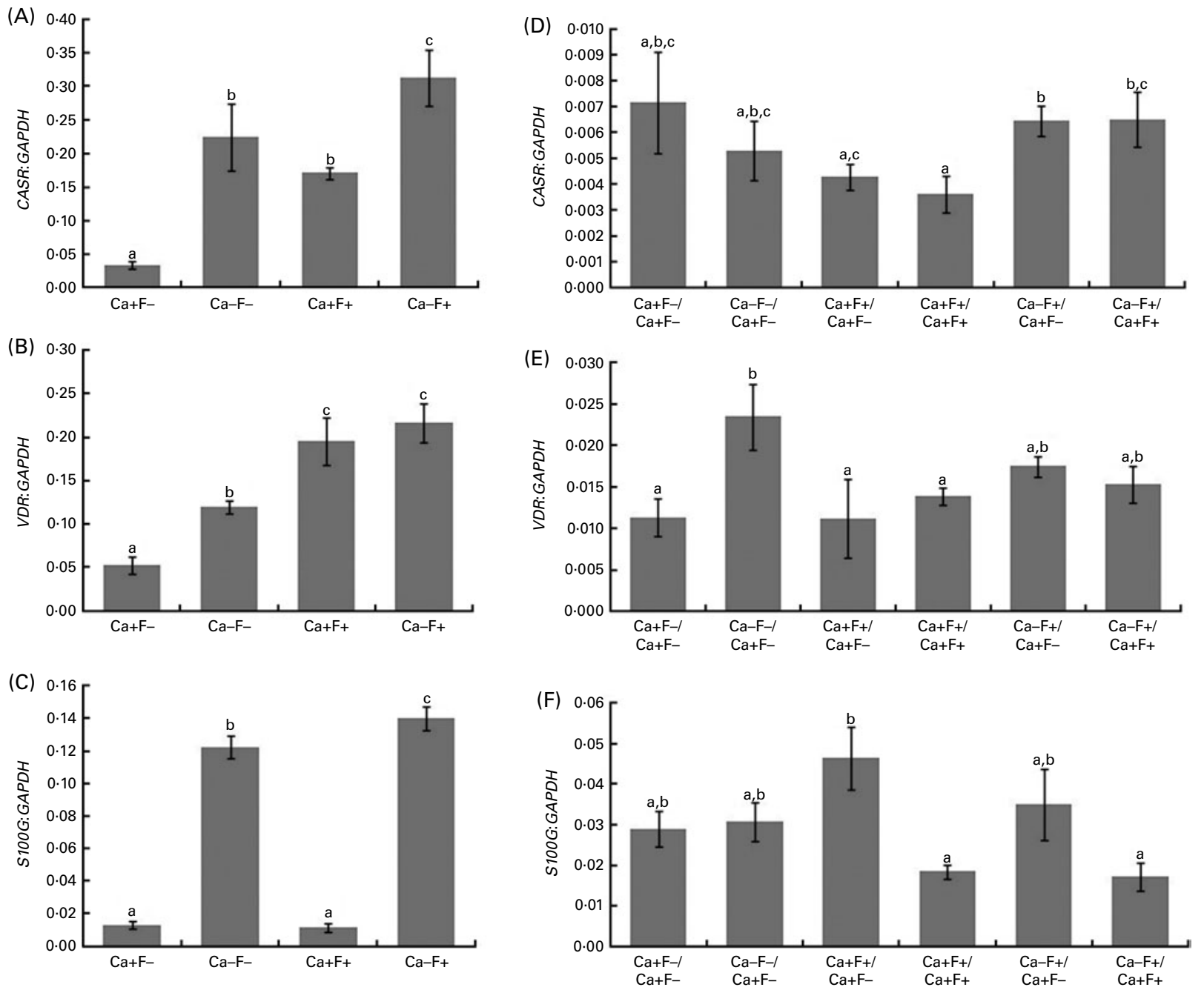

Fig. 3. (A) Expression of calcium-sensing receptor $(C A S R)$, there were significant main effects for calcium $(P=0.001)$, fluoride $(P=0.003)$ and calcium $\times$ fluoride $(P=0.503)$; (B) vitamin $\mathrm{D}$ receptor $(V D R)$, there were significant main effects for calcium $(P=0.040)$, fluoride $(P=0.001)$ and calcium $\times$ fluoride $(P=0.265)$; $(C)$ S100 calcium-binding protein $\mathrm{G}(S 100 G)$, there were significant main effects for calcium $(P=0.001)$, fluoride $(P=0.069)$ and calcium $\times$ fluoride $(P=0.029)$ normalised to glyceraldehyde-3-phosphate dehydrogenase $(G A P D H)$ in the duodenal mucosa of rats fed a normal-calcium $(0.5 \%)$ diet $(\mathrm{Ca}+\mathrm{F}-)$, a low-calcium $(0.25 \%)$ diet $(\mathrm{Ca}-\mathrm{F}-)$, the normal-calcium $(0.5 \%)$ diet +100 parts per million $(\mathrm{ppm})$ fluoride $(\mathrm{Ca}+\mathrm{F}+)$, or the low-calcium $(0.25 \%)$ diet $+100 \mathrm{ppm}$ fluoride $(\mathrm{Ca}-\mathrm{F}+)$ for 6 months in phase I. Expression of (D) CASR, (E) VDR and (F) S100G normalised to GAPDH in duodenal mucosa of rats after providing the normal-calcium $(0.5 \%)$ diet and fluoride-free water treatment in phase II (reversal phase, duration 3 months) of the study. In (D), (E) and (F), the characters preceding the '/" on the $x$ the axis refer to the dietary treatment in phase I and the characters following the '" refer to the dietary treatment in phase II. Values are means, with their standard errors represented by vertical bars. Phase I, $\mathrm{Ca}+\mathrm{F}-(n 12), \mathrm{Ca}-\mathrm{F}-(n 16), \mathrm{Ca}+\mathrm{F}+$ and $\mathrm{Ca}-\mathrm{F}+(n$ 24); phase II, $n 8$ except $\mathrm{Ca}+\mathrm{F}-/ \mathrm{Ca}+\mathrm{F}-$ treatment group $(n 6) .{ }^{\mathrm{a}, \mathrm{b}, \mathrm{c}}$ Mean values with unlike letters are significantly different $(P<0.05)$.

to the increased demand of $\mathrm{Ca}$ for new bone formation in fluorosis, lowering of serum $\mathrm{Ca}$ has been reported earlier also $^{(10,11)}$. In phase II, after replacing the LCD with the NCD, treatment groups $\mathrm{Ca}-\mathrm{F}+/ \mathrm{Ca}+\mathrm{F}-$ and $\mathrm{Ca}-\mathrm{F}+/ \mathrm{Ca}+\mathrm{F}+$ could not show significant recovery in serum $\mathrm{Ca}$. The group receiving $\mathrm{Ca}+\mathrm{F}+$ in phase I was divided into two subgroups to compare the effects of continuation $v$. discontinuation of $\mathrm{F}$, and it was found that the serum $\mathrm{Ca}$ of the treatment group $\mathrm{Ca}+\mathrm{F}+/ \mathrm{Ca}+\mathrm{F}-$ improved $(P=0 \cdot 48)$.

Serum $25(\mathrm{OH})$ vitamin $\mathrm{D}_{3}$ in treatment groups $\mathrm{Ca}-\mathrm{F}-$ and $\mathrm{Ca}-\mathrm{F}+$ was low, whereas serum $1,25(\mathrm{OH})_{2}$ vitamin $\mathrm{D}_{3}$ was high due to increased enzymatic conversion of $1,25(\mathrm{OH})_{2}$ vitamin $\mathrm{D}_{3}$ from $25(\mathrm{OH})$ vitamin $\mathrm{D}_{3}$ to promote intestinal absorption of $\mathrm{Ca}^{(18)}$. In phase $\mathrm{II}$, after receiving the $\mathrm{NCD}$, serum $25(\mathrm{OH})$ vitamin $\mathrm{D}_{3}$ and $1,25(\mathrm{OH})_{2}$ vitamin $\mathrm{D}_{3}$ of treatment groups $\mathrm{Ca}-\mathrm{F}-/ \mathrm{Ca}+\mathrm{F}-, \mathrm{Ca}-\mathrm{F}+/ \mathrm{Ca}+\mathrm{F}-$ and $\mathrm{Ca}-\mathrm{F}+/ \mathrm{Ca}+\mathrm{F}+$ were comparable with other groups. A significant increase in expression of CASR levels in treatment groups $\mathrm{Ca}-\mathrm{F}-$ (6-fold), $\mathrm{Ca}+\mathrm{F}+(4.5$-fold) and $\mathrm{Ca}-\mathrm{F}+$ (9fold), as compared with $\mathrm{Ca}+\mathrm{F}-$, was observed as reported previously also ${ }^{(22)}$. The reason behind significant increases of $V D R$ and $\$ 100 G$ expression levels in LCD-treated groups in phase I was $\mathrm{Ca}$ insufficiency, in which expression of $V D R$ is up-regulated ${ }^{(44)}$. VDR is known to induce $S 100 G$ transcription in the intestine ${ }^{(45,46)}$ and facilitates the intracellular diffusion of $\mathrm{Ca}^{(47)}$ to maintain $\mathrm{Ca}$ homeostasis. There was significant increase in the $V D R$ expression levels of the treatment group $\mathrm{Ca}+\mathrm{F}+$, but without any significant increase in either serum $1,25(\mathrm{OH})_{2}$ vitamin $\mathrm{D}_{3}$ levels or S100G expression. Studies ${ }^{(48,49)}$ have suggested that the increase in 
$V D R$ expression may also be due to post-translational events, resulting in increased receptor stability ${ }^{(50)}$.

In phase II, after providing the NCD, CASR (except treatment groups $\mathrm{Ca}-\mathrm{F}+/ \mathrm{Ca}+\mathrm{F}-$ and $\mathrm{Ca}-\mathrm{F}+/ \mathrm{Ca}+\mathrm{F}+)$ and $V D R$ (except treatment group $\mathrm{Ca}-\mathrm{F}-/ \mathrm{Ca}+\mathrm{F}-$ ) expressions of all other groups were comparable. Down-regulation of any of the receptors studied was not observed in the presence of $\mathrm{F}$ in phase I. However, in phase II, S100G expression of F-treated groups $\mathrm{Ca}+\mathrm{F}+/ \mathrm{Ca}+\mathrm{F}+(2 \cdot 5$-fold $)$ and $\mathrm{Ca}-\mathrm{F}+/$ $\mathrm{Ca}+\mathrm{F}+(2$-fold) was down-regulated (as compared with treatment group $\mathrm{Ca}+\mathrm{F}+/ \mathrm{Ca}+\mathrm{F}-$ ), as reported previously also ${ }^{(22)}$. This observation suggests that in the long term, irrespective of nutritional background, chronic $\mathrm{F}$ toxicity may reduce $\mathrm{Ca}$ absorption by inhibiting the expression of S100G, a key molecule involved in active $\mathrm{Ca}$ transport in the intestine ${ }^{(20,21)}$, resulting in adverse effects on $\mathrm{Ca}$ homeostasis. A protein expression study could not be carried out, which is the limitation of the present study.

In summary, chronic $\mathrm{F}$ toxicity along with inadequate $\mathrm{Ca}$ showed adverse effects on BWG, FER and $\mathrm{Ca}$ homeostasis in phase I. However, irrespective of Ca nutrition, F toxicity down-regulated S100G expression in phase II. A NCD treatment improved BWG irrespective of the type of water administered, and there was better improvement in FER of the LCD + F-treated group after receiving the NCD and FFW for 3 months. Ca homeostasis appeared to be normalised at the end of phase II. It is concluded that adverse effects of chronic $\mathrm{F}$ toxicity are more pronounced in the presence of $\mathrm{Ca}$ deficiency. These effects may be ameliorated with adequate $\mathrm{Ca}$ nutrition and safe drinking water. Chronic $\mathrm{F}$ toxicity may affect $\mathrm{Ca}$ absorption in the duodenum due to the inhibitory effect on the expression of S100G - a key molecule involved in $\mathrm{Ca}$ absorption. Further studies are required to study the protein content of CASR, VDR and S100G. In addition, human studies are needed to explore the reversibility of fluorosis.

\section{Acknowledgements}

The present study was supported by the Indian Council of Medical Research, India. We thank N. Hari Shankar, for providing facilities for animal experimentation and acknowledge expert technical assistance of G. Shanker Rao and P. Krishna Swamy (atomic absorption spectrometer). We also thank Bharti Kulkarni, for critical review of the manuscript. None of the authors had a personal or financial conflict of interest. A. L. K. designed the study; P. S. conducted the research and laboratory analysis; S. G. supervised molecular biology work; K. B. guided the analysis of Ca; K. V. guided the statistical analysis of data; and P. S. and A. L. K. wrote the paper and had primary responsibility for the final content. All authors read and approved the final manuscript.

\section{References}

1. World Health Organization (2003) Background Document for Preparation of WHO Guidelines for Drinkingwater Quality. Fluoride in Drinking-water. Geneva: WHO. http://www.who.int/water_sanitation_health/dwq/chemicals/ fluoride.pdf

2. Planning Commission, India (2007) Eleventh five-year plan approach paper. Rural water supply and sanitation. http:// planningcommission.gov.in/aboutus/committee/wrkgrp11/wg 11_comble.pdf

3. Anusuya A (1996) Fluorosis. In Textbook of Human Nutrition, pp. 424-440 [MS Bamji, PN Rao and V Reddy, editors] New Delhi: Oxford \& IBH Publishing Company.

4. Krishnamachari KAVR (1986) Skeletal fluorosis in humans; a recent progress in the understanding of the disease. Prog Food Nutr Sci 10, 279-314.

5. Khandare AL, Kumar PU, Shankar HN, et al. (2007) Effect of calcium deficiency induced by fluoride intoxication on lipid metabolism in rabbits. Fluoride 40, 184-189.

6. Coetze CB, Casey NH \& Meyer JA (1997) Fluoride tolerance of laying hens. Br Poult Sci 38, 597-602.

7. Dunipace AJ, Edward JB, Wilson ME, et al. (1998) Chronic fluoride exposure does not cause detrimental, extra skeletal effects in nutritionally deficient rats. J Nutr 128, 1392-1400.

8. Lohakare J, Pattanaik A \& Khan SA (2010) Effect of long-term fluoride exposure on growth, nutrient utilization and fluoride kinetics of calves fed graded levels of dietary protein. Biol Trace Elem Res 138, 148-162.

9. Turner CH, Garetto LP, Dunipace AJ, et al. (1997) Fluoride treatment increased serum IGF-1, bone turnover, and bone mass but not bone strength in rabbits. Calcif Tissue Int 61, $77-83$.

10. Das TK \& Susheela AK (1993) Effect of long-term administration of sodium fluoride on plasma calcium level in relation to intestinal absorption and urinary excretion in rabbits Environ Res 62, 14-18.

11. Khandare AL, Harikumar R \& Sivakumar B (2005) Severe bone deformities in young children from vitamin D deficiency and fluorosis in Bihar-India. Calcif Tissue Int 76, 412-418.

12. Gruber HE \& Baylink DJ (1991) The effects of fluoride on bone. Clin Orthop Relat Res 267, 264-277.

13. Kleerekoper M \& Mendlovic DB (1993) Sodium fluoride therapy of postmenopausal osteoporosis. Endocr Rev $\mathbf{1 4}$ $312-323$

14. Krishnamachari KA (1986) Skeletal fluorosis in humans: a review of recent progress in the understanding of the disease. Prog Food Nutr Sci 10, 279-314.

15. Gupta SK, Gambhir S, Mithal A, et al. (1993) Skeletal scintigraphic findings in endemic skeletal fluorosis. $\mathrm{NuCl} \mathrm{Med}$ Commun 14, 384-390.

16. Saidak Z, Mentaverri R \& Brown EM (2009) The role of the calcium-sensing receptor in the development and progression of cancer. Endocr Rev 30, 178-195.

17. Koroglu BK, Ersoy IH, Koroglu M, et al. (2011) Serum parathyroid hormone levels in chronic endemic fluorosis. Biol Trace Elem Res 143, 79-86.

18. Kochupillai N (2008) The physiology of vitamin D: current concepts. Indian J Med Res 127, 256-262.

19. Jones G, Strugnell SA \& DeLuca HF (1998) Current understanding of the molecular actions of vitamin D. Physiol Rev 78, 1193-1231.

20. Bronner F (1996) Calcium transport across epithelia. Int Rev Cytol 131, 169-212.

21. Christakos S, Gill R, Elee S, et al. (1992) Molecular aspects of the calbindins. J Nutr 122, 678-682.

22. Tiwari S, Gupta SK, Kumar K, et al. (2004) Simultaneous exposure of excess fluoride and calcium deficiency alters VDR, CAR, and calbindin D $9 \mathrm{k}$ mRNA levels in rat duodenal mucosa. Calcif Tissue Int 75, 313-320. 
23. Ranganathan S (1941) Calcium intake and fluorine poisoning in rats. Indian J Med Res 29, 693-697.

24. Burkhart JM \& Jowsey J (1968) Effect of variation in calcium intake on the skeleton of fluoride-fed kittens. J Lab Clin Med 72, 943-950.

25. Srikantia SG \& Siddiqui AH (1965) Metabolic studies in skeletal fluorosis. Clin Sci 28, 477-485.

26. Reddy GS \& Rao BSN (1971) Effect of dietary calcium, vitamin $\mathrm{C}$ and protein in development of experimental skeletal fluorosis II calcium turnover with ${ }^{45} \mathrm{Ca}$; calcium and phosphorus studies. Metabolism 20, 650-656.

27. Singh A \& Jolly SS (1961) Endemic fluorosis: epidemiological, clinical and biochemical study of chronic fluoride intoxication in Punjab (India). Medicine 42, 229-246.

28. Mithal A, Trivedi N, Gupta SK, et al. (1993) Radiological spectrum of endemic fluorosis: relationship with calcium intake. Skeletal Radiol 22, 257-261.

29. National Nutrition Monitoring Bureau, National Institute of Nutrition, Hyderabad (2006) Report on diet and nutrition status of population and prevalence of hypertension among adults in rural areas. http://www.nnmbindia.org/ NNMBReport06Nov20.pdf

30. Indian Council of Medical Research (2010) Nutrient Requirement and Recommended Dietary Allowances for Indians. A Report of the Expert Group of ICMR, pp. 122-134. Hyderabad, India: National Institute of Nutrition.

31. Harinarayan CV, Ramalakshmi T, Prasad UV, et al. (2007) High prevalence of low dietary calcium, high phytate consumption, and vitamin D deficiency in healthy south Indians. Am J Clin Nutr 85, 1062-1067.

32. Eleventh five-year plan (2007) Agriculture rural development, industry, services and physical infrastructure 2007-12, volume III. http://planningcommission.nic.in/ plans/planrel/fiveyr/11th/11_v3/11th_vol3.pdf

33. Reeves GP, Nielsen FH \& Fahey GC (1993) AIN-93 purified diets for laboratory rodents: final report of the American Institute of Nutrition ad hoc writing committee on the formulation of the AIN-76A rodent diet. J Nutr 123, 1939-1951.

34. Teotia SPS, Teotia M, Singh DP, et al. (1984) Environmental fluoride and metabolic bone disease - an epidemiological study (fluoride and nutrient interaction). Fluoride 17, 14-22.

35. Angmar-Mansson B \& Whitford GM (1982) Plasma fluoride levels and enamel fluorosis in the rat. Caries Res 16, 334-339.

36. Dunipace AJ, Brizendine EJ, Zhang W, et al. (1995) Effect of aging on animal response to chronic fluoride exposure. $J$ Dent Res 74, 358-368.

37. Arancha B, Ana N, Sara B, et al. (2008) A nori but not a konbu dietary supplement decreases the cholesterolaemia, liver fat infiltration and mineral bioavailabiliy to hypercholesterolaemic growing wistar rats. Br J Nutr 99, 272-280.

38. Perkin Elmer Corp. (1971) Analytical Method for Atomic Absorption Sepectrometry. Norwalk, CT: Perkin Elmer Corp.

39. Singer L \& Armstrong WD (1968) Determination of fluoride in bone with the fluoride electrode. Anal Chem 40, 613-614.

40. Mendoza FJ, Lopez I, Canalejo R, et al. (2009) Direct upregulation of parathyroid calcium sensing receptor and vitamin D receptor by calcimimetics in uremic rats. Am J Physiol Renal Physiol 296, F605-F613.

41. Charoenphandhu N, Nakkrasae L, Kraidith K, et al. (2009) Two-step stimulation of intestinal $\mathrm{Ca}^{2+}$ absorption during lactation by long-term prolactin exposure and suckling induced prolactin surge. Am J Physiol Endocrinol Metab 297, E609-E619

42. Kuroda S, Virdi AS, Dai Y, et al. (2005) Patterns and localization of gene expression during intramembraneous bone regeneration in the rat femoral marrow ablation model. Calcif Tissue Int 77, 212-225.

43. Xu H, Liu QY, Zhang JM, et al. (2010) Elevation of PTH and PTHrp induced by excessive fluoride in rats on a calciumdeficient diet. Biol Trace Elem Res 137, 79-87.

44. McDonnell DP, Mangelsdorf DJ, Pike JW, et al. (1987) Molecular cloning of complementary DNA encoding the avian receptor for vitamin D. Science 235, 1214-1217.

45. Theofan G, Nguyen AP \& Norman AW (1986) Regulation of calbindin-D28K gene expression by 1,25-dihydroxyvitamin $\mathrm{D}_{3}$ is correlated to receptor occupancy. J Biol Chem 261, 16943-16947.

46. Dupret JM, Brun P, Perret C, et al. (1987) Transcriptional and post-transcriptional regulation of vitamin D-dependent calcium-binding protein gene expression in the rat duodenum by 1,25-dihydroxycholecalciferol. J Biol Chem 262, $16553-16557$

47. Wasserman RH \& Fullmer CS (1983) Calcium transport proteins, calcium absorption and vitamin D. Annu Rev Physiol 45, 375-390.

48. Strom M, Sandgren M, Brown T, et al. (1989) 1,25-Dihydroxyvitamin D3 up-regulates the 1,25-dihydroxyvitamin $\mathrm{D}_{3}$ receptor in vivo. Proc Natl Acad Sci 86, 9770-9773.

49. Goff JP, Reinhardt T, Beckman M, et al. (1990) Contrasting effects of exogenous 1,25-dihydroxyvitamin D [1,25$\left.(\mathrm{OH})_{2} \mathrm{D}\right]$ vs. endogenous $\left[1,25-(\mathrm{OH})_{2} \mathrm{D}\right]$, induced by dietary calcium restriction, on vitamin D receptors. Endocrinology 126, 1031-1035.

50. Favus MJ, Mangelsdorf DJ, Timbe V, et al. (1988) Evidence for in vivo upregulation of the intestinal vitamin $\mathrm{D}$ receptor during dietary calcium restriction in the rat. J Clin Invest $\mathbf{8 2}$, $218-224$. 